\title{
VARIASI NAMA TUHAN DALAM TEKS SERAT SASTRA GENDHING, KAJIAN AKULTURASI TERHADAP SASTRA SULUK
}

\author{
Yuli Kurniati Werdiningsih', Nazla Maharani Vmaya ${ }^{2}$ \\ ${ }^{1}$ Program Studi Pendidikan Bahasa dan Sastra Daerah \\ Universitas PGRI Semarang \\ ${ }^{2}$ Program Studi Pendidikan Bahasa dan Sastra Indonesia \\ Universitas PGRI Semarang \\ Email: yulikwerdi@gmail.com
}

\section{Abstract}

The purpose of this study is to describe the mechanism interculturalism in "Serat Sastra Gendhing" focusing on the mechanisms acculturation. This research is motivated by the concept that the Suluk is a product of cultural contacts. In order to achieve its objectives, this study used qualitative method and supported by interculturalism theory. The result of this research is the discovery of variations in mentioning the Lord that is the product of contact between Javanese culture, Hinduism, and Islam. Variations of the name of the Lord found are Hyang, Widdhi, Hyang Manon, Pangeran, Allah Kudusul Almi, and Gusti Allah.

Tujuan penelitian ini adalah mendeskripsikan mekanisme interkulturalisasi dalam Serat Sastra Gendhing (SSG), yang difokuskan pada mekanisme akulturasi. Penelitian ini dilatarbelakangi konsep bahwa sastra suluk merupakan produk kontak budaya. Guna mencapai tujuan penelitian tersebut, maka digunakan metode kualitatif dan didukung dengan teori interkulturalisasi. Hasil dari penelitian ini adalah berbagai variasi penyebutan nama Tuhan yang merupakan produk dari kontak budaya Jawa, Hindu, dan Islam. Variasi nama Tuhan yang ditemukan di antaranya adalah Hyang, Widdhi, Hyang Manon, Pangeran, Allah Kudusul Almi, dan Gusti Allah. 
Keywords: acculturation; the name of the Lord; cultural contacts; suluk

\section{Pendahuluan}

Kebudayaan Jawa dapat disebut sebagai kebudayaan yang heterogen karena terdiri dari beranekaragam unsur kebudayaan. Keanekaragaman tersebut bersifat regional sepanjang daerah Jawa Tengah dan Jawa Timur. Bentuk keanekaragaman tersebut dapat dilihat dari munculnya budaya pesisir dan kraton. Budaya pesisir adalah budaya yang hidup di lingkungan pesisir pantai utara (dari Indramayu-Cirebon-Pekalongan-Demak-Gresik). Budaya kraton merupakan budaya yang hidup di Yogyakarta dan Solo. Budaya kraton ini mempunyai sejarah kesusastraan yang telah ada sejak empat abad lalu, yang di dalamnya terdapat campuran dari unsur-unsur agama dan budaya Hindu, Budha, serta Islam (Koentjaraningrat, 1994: 25-26).

Sebelum masuknya Islam ke Jawa, Hindu adalah salah satu unsur utama dalam budaya Jawa. Di Jawa, budaya Hindu menyebar melalui pemahaman dan pengolahan yang dilakukan golongan bangsawan serta para cendekiawan Jawa (Simuh, 1988:1). Bahasa Sansekerta dan huruf Jawa yang berasal dari huruf Pallawa adalah wujud nyata dari pengolahan budaya Hindu yang dilakukan para cendekiawan. Kaum bangsawan merupakan pintu berikutnya dalam perkembangan budaya Hindu di Jawa. Kaum bangsawan yang senantiasa berkomunikasi dengan para abdi menularkan budaya Hindu di Jawa melalui para abdinya ini. Selanjutnya, para abdi memperluas jaringan Hindu di Jawa melalui golongannya (rakyat di luar istana).

Pintu utama masuknya Islam di Jawa adalah daerah-daerah pesisir pantai utara Jawa yang merupakan tempat bertemunya berbagai macam unsur budaya, termasuk agama. Perkembangan Islam di Jawa diawali dari kalangan syiah yang merupakan golongan kebatinan yang bertujuan untuk menyampaikan kebenaran ajaran baru. Berikutnya golongan ahlus sunnah wal-jamaah yang dikenal sebagai pedagang (Woorward, 2004: x). Menurut Koentjaraningrat (1994: 316) pada paruh kedua abad ke-16 pengaruh Islam dari daerah timur laut berhasil masuk ke pedalaman Jawa. Masuknya Islam di Jawa bukan tanpa perlawanan dari para raja di Jawa, khususnya Mataram. Sampai pada akhir abad ke-17 ketika kekuatan Mataram mulai melemah, Islam mulai masuk melalui daerah pedesaan dengan memanfaatkan pengubahan pendidikan mandala menjadi pesantren. 
Pendirian pesantren-pesantren menjadikan Islam lebih leluasa masuk ke dalam lingkungan masyarakat Jawa dan meluaskan jaringannya. Seiring meluasnya Islam di Jawa, budaya Jawa pun berkembang dari yang semula hanya berakarkan budaya Hindu menjadi bernafaskan Islam. Meskipun demikian, budaya Jawa tidak meninggalkan akar budaya Hindu dalam perkembangannya. Menurut Simuh (1988: 22) hal ini wajar karena pada saat peralihan kekuasan dari kerajaan Jawa-Hindu Majapahit ke kerajaan Jawa-Islam Demak terjadi kontak langsung antara budaya Jawa-Hindu dengan Islam. Wujud budaya Jawa yang merepresentasikan adanya kontak budaya dari unsur Islam dan Hindu dapat dilihat pada upacara adat (pawiwahan, slametan, sedekah bumi); seni bangunan (tempat ibadah, rumah); bahasa, perhitungan kosmologis (tahun, bulan, hari); dan karya sastra.

Beberapa jenis karya sastra Jawa yang merefleksikan adanya interkulturalisasi adalah kakawin, kidung, wirid dan suluk. Kakawin dan kidung merupakan hasil interkulturalisasi dari Hindu dan Jawa, sedangkan wirid dan suluk merupakan hasil dari interkulturalisasi Hindu dan Islam. Hal ini dibuktikan dengan berbagai konsep Hindu yang dipadukan dengan konsep Jawa dalam kakawin dan kidung, sedangkan dalam wirid dan suluk ditemukan perpaduan konsep Hindu dan Islam (Imam, 2005).

Proses interkuturalisasi tidak terjadi secara instan. Menurut Salam (2011: 51) dalam prosesnya, terdapat tujuh kategori mekanisme interkulturalisasi yakni : 1) nasihat dan ideologisasi; 2) migrasi, akulturasi, dan asimilasi; 3) pelatihan dan pendisiplinan; 4) teknologisasi dan industrialisasi; 5) bertambahnya pengalaman; 6) konflik dan kekerasan; 7) persuasi kesenian. Dalam penelitian ini mekanisme akulturasi akan dijadikan dasar pijakan. Akulturasi berasal dari bahasa Inggris acculturation yang berarti pengambilan atau penerimaan satu atau beberapa kebudayaan yang berasal dari pertemuan dua atau beberapa kebudayaan yang saling berhubungan atau saling bertemu (Suyono, 1985: 15). Secara leksikal akulturasi berarti proses percampuran dua kebudayaan atau lebih yang saling bertemu dan saling mempengaruhi, proses atau hasil pertemuan kebudayaan atau bahasa di antara anggota-anggota dua masyarakat bahasa, ditandai dengan peminjaman atau bilingualisme (Tim Penyusun, 1986: 18). Menurut Havilland (1993: 263) akulturasi adalah perubahan-perubahan besar yang terjadi sebagai akibat dari kontak antar kebudayaan yang berlangsung lama.

Dalam batas-batas tertentu nilai-nilai ras dan etnisitas dapat dipertemukan dengan adanya proses akulturasi. Proses akulturasi merupakan proses sosial 
bertemunya dua kebudayaan atau lebih. Biasanya kebudayaan asli orang (kelompok) tersebut tidak hilang, tetapi seolah mengalami modifikasi. Proses akulturasi tidak dapat dipetakan dalam kategori dan proses yang sederhana. Hal itu dikarenakan variabel yang dimungkinkan bercampur aduk dengan konteks aktual yang terjadi, seperti tingkat pendidikan, kelas atau status sosial ekonomi, usia dan pengalaman hidup, gender, lingkungan, dan sejarah sosial serta latar belakang budaya (Salam, 2011: 47). Akulturasi dipilih karena mekanisme ini sesuai dengan data-data hasil kontak kebudayaan dalam SSG yang berupa kata dan frasa mengenai variasi nama Tuhan yang merupakan bentuk bilingualisme dan memperlihatkan adanya pertemuan antar budaya.

\section{Metode Penelitian}

Pendekatan kualitatif digunakan dalam penelitian ini, karena temuan dalam penelitian ini berupa fenomena yang belum terungkap dan tidak diperoleh melalui prosedur statistik atau bentuk hitungan (Strauss \& Corbin, 2009: 4-5). Hal ini didasari pula dari sifat datanya, yakni data kualitatif. Data dalam penelitian ini berupa kata, frasa, klausa, kalimat dan wacana berkait dengan realitas sosial dan interkulturalisasi yang terdapat dalam teks SSG. Selain itu data juga berasal dari berbagai media yang memuat masalah-masalah sosial akibat kontak budaya. Sumber data yang digunakan dalam penelitian adalah teks SSG yang merupakan hasil suntingan secara filologis dari Werdiningsih (2006) dan berbagai wacana berkait dengan permasalahan penelitian.

Data dalam penelitian yang berupa kata, frasa, kalimat, dan wacana dikumpulkan melalui proses menerjemahkan; klasifikasi; identifikasi; inventarisasi. Kesemua proses dilakukan diiringi dengan teknik pencatatan. Teks SSG yang akan digunakan berbahasa Jawa dan berbentuk tembang macapat. Oleh karena itu, sebelum dianalisis dilakukan proses penerjemahan untuk mempermudah menemukan data yang berhubungan dengan masalah penelitian. Penerjemahan dilanjutkan dengan proses klasifikasi, guna mendapatkan kelompok-kelompok data sesuai dengan masalah penelitian. Hasil dari penerjemahan akan diidentifikasi dan diberi nomor sesuai dengan kelas masing-masing data. Upaya identifikasi dilakukan guna mempermudah peneliti dalam menginventarisasi data. Inventarisasi digunakan untuk mengetahui kompleksitas dari keseluruhan data yang akan dianalisis.

Metode analisis data dalam penelitian ini menggunakan metode kepustakaan yang menitikberatkan pada kajian pustaka yang relevan dengan 
permasalahan dalam penelitian. Teknik analisis triangulasi, yakni reduksi data; interpretasi data dan penarikan simpulan.

\section{Temuan dan Diskusi}

SSG berbentuk tembang macapat dan terbagi dalam lima pupuh yaitu Sinom, Asmaradana, Dhandhanggula, Pangkur dan Durma. Kelima pupuh tersebut terdiri atas 73 bait dengan susunan sebagai berikut. Pupuh Sinom terdiri atas 13 bait, pupuh Asmaradana terdiri atas 12 bait, pupuh Dhandhanggula terdiri atas 11 bait, pupuh Pangkur terdiri atas 17 bait, sedangkan pupuh Durma terdiri atas 20 bait.

Dalam SSG nama Tuhan disebut dengan istilah yang bervariasi. Istilah-istilah tersebut berasal dari bahasa Arab, Sansekerta dan Jawa Kuno. Penggunaan bahasa-bahasa tersebut menunjukkan proses interkulturalisasi. Proses interkulturalisasi terjadi karena bahasa Sansekerta merupakan bahasa yang menunjukkan tradisi Hindu yang berasal dari India bagian Utara. Bahasa Arab merupakan bahasa yang digunakan dalam tradisi penyebaran Islam, sedangkan bahasa Jawa Kuno merupakan bahasa asli Jawa yang telah digunakan masyarakat Jawa.

Teks SSG merupakan karya sastra yang ditulis pada masa kerajaan Mataram, sehingga dapat dikategorikan dalam periode kesastraan Jawa Baru (Zoetmuder, 1983: 2). Sebagai bagian dari karya sastra Jawa Baru, maka dapat diasumsikan bahwa bahasa dalam teks SSG merupakan perpaduan dari bahasa Jawa Baru, Jawa Kuno, Sansekerta, dan Arab. Masing-masing bahasa tersebut mewakili latar belakang budaya yang juga berbeda. Selain itu, sebagai bagian dari karya sastra berjenis suluk teks SSG memuat ajaran tentang ketuhanan yang bernafaskan Islam. Oleh karena itu, dalam teks SSG ditemukan berbagai variasi nama Tuhan yang memperlihatkan adanya variasi latar belakang budaya.

Analisis variasi nama Tuhan diawali dengan menemukan asal kata dan bahasanya. Proses awal ini dilakukan untuk mempermudah proses penafsiran yang disesuaikan dengan konteks budaya yang melatarbelakangi masing-masing nama Tuhan tersebut. Dua proses tersebut bertujuan untuk menemukan mekanisme interkulturalisasi melalui akulturasi dalam variasi nama Tuhan dalam SSG.

Bahasa yang digunakan dalam SSG adalah bahasa Jawa Baru dengan ragam bahasa ngoko dan krama. Guna mempermudah pemahaman pembaca dan karena teks SSG berbahasa Jawa Baru, maka kutipan yang berisi variasi nama Tuhan diberi terjemahan. Setiap kutipan diberi kode sesuai dengan nomor 
pupuh, bait, dan baris. Pupuh diberi kode $\mathrm{P}$, nomor pupuh menggunakan angka Romawi I--V. Bait disebut b, nomor bait menggunakan angka Arab 1, 2, 3, dst. Setiap pergantian pupuh, nomor bait dimulai dari awal. Baris diberi kode angka Arab, sesuai dengan nomor baris dalam bait tersebut. Setiap pergantian bait, nomor baris dimulai dari awal. Pupuh, dan bait diberi jeda tanda titik (.), sedangkan bait dan baris diberi tanda titik dua (:).Contoh (P.III. b4:5), berarti kutipan diambil dari pupuh III, bait empat, baris lima. Pergantian baris diberi tanda $(/)$. Kode-kode tersebut ditulis dibelakang setiap kutipan. Adapun variasi nama Tuhan dalam SSG adalah sebagai berikut.

\section{Hyang}

Kata Hyang digunakan dalam SSG untuk menyebut nama Tuhan. Kata Hyang disebut secara mandiri maupun digabungkan dengan kata yang lain, misalnya Manon dan Widdhi. Hyang digunakan secara mandiri dalam beberapa bagian teks, diantaranya pada kalimat ananing Hyang saking akal 'adanya Hyang dari akal' (P.II.b3:7) dan saking dening wit samar kahananing Hyang 'karena berawal dari ketidakjelasan keberadaan Hyang' (P.V.b4:1). Kata Hyang berasal dari bahasa Jawa Kuno hyang, yang berarti 'dewa, dewi, yang dipuja sebagai dewa, Tuhan, dewa yang khusus bertalian dengan tempat (kraton, kayu, dsb)'; 'yang berhubungan dengan dewa; hal-hal yang suci, orang yang berbakti kepada kesucian, yang taat kepada agama, pertapa, biarawati, biarawan'; kata hyang sering berada di depan kata benda (Zoetmulder \& Robson, 1995:373).

Berdasarkan dua kutipan dan data tersebut, maka dapat diketahui bahwa kata Hyang digunakan untuk menyebut nama Tuhan dalam tradisi dan budaya Jawa Kuno, yakni abad ke-9 sampai abad ke-11 (Zoetmulder, 1983:4). Kata Hyang merepresentasikan interkulturalisme karena berasal dari budaya Jawa Kuno dan digunakan dalam wacana Jawa Baru. Oleh karena itu, kata Hyang telah mengalami akulturasi dari budaya Jawa Kuno yang masih kental dengan budaya Hindu ke budaya Jawa Baru yang telah memasuki budaya Islam. Penggunaan kata Hyang menunjukkan adanya bentuk kontak budaya Islam dengan Hindu, yakni penggunaan kosakata dari tradisi budaya Hindu dalam wacana sastra suluk yang bernafaskan Islam.

Kata Hyang Suksma digunakan untuk menyebut nama Tuhan dan digabungkan dengan kata Suksma. Kata Hyang Suksma hanya digunakan satu kali dalam teks SSG. Adapun kutipan mengenai penggunaan kata Hyang Suksma sebagai berikut reh ananing Hyang Suksma/ amurweng gumlaring bumi "hal tentang keberadaan Hyang Suksma adalah yang mengawali bentangan bumi" 
(P.V.b7:4-5). Kata Hyang yang berasal dari bahasa Jawa Kuno Hyang mengawali kata Suksma. Kata suksma berasal dari bahasa Sansekerta fine, small, thin, narrow, delicate, acute, intellect, mental operation, nice, exact (Macdonell, 1954: 386). Secara berurutan dapat diartikan sebagai berikut: sangat baik, kecil, tipis, kecil, lembut, hangat, cerdas, kegiatan mental, persis (Echols \& Sadilly, 1989).

Dalam bahasa Jawa Kuno, suksma berarti halus, dari bahan yang lembut, sangat halus (ringan), tidak bersubtansi, ialah tidak dapat diterima (diperoleh) dengan alat-alat persepsi biasa, tetapi dapat dimengeri atau tampak oleh barangsiapa yang memiliki kekuatan supernatural, immaterial, kedewaan, menifestasi supernatural dari dunia lain; mengambil bentuk tidak tampak, menghilang; halus lembut dan berliku-liku (Zoetmulder \& Robson, 1995: 1139).

Dalam konteks ini kata Hyang Suksma berarti 'Tuhan yang tidak tampak akan tetapi memiliki kekuatan supernatural sehingga dapat mengawali bentangan bumi'. Mengawali bentangan bumi adalah kata lain dari pencipta bumi, jadi Hyang Suksma diartikan sebagai 'Tuhan Yang Maha Pencipta'. Kata Hyang Suksma merupakan perwujudan akulturasi karena didalamnya terdapat bilingualisme, atau percampuran dua bahasa yang berbeda, yakni dari bahasa Jawa Kuno dan bahasa Sansekerta. Bahasa Jawa Kuno mewakili budaya Jawa, sedangkan bahasa Sansekerta mewakili budaya India (Hindu). Oleh karena itu, kata Hyang Suksma dapat dikategorikan kata yang mengalami mekanisme interkulturalisasi. Frasa Hyang Suksma sepadan dengan variasi nama Tuhan dalam teks SSG yang berikunya yakni Kang Akarya Jagad. Kang Akarya Jagad berasal dari bahasa Jawa Baru yang berarti 'Yang Menciptakan Dunia' (Prawiroatmodjo, 1980: 14, 98 \& 145). Dalam konteks ini Kang Akarya Jagad diartikan sebagai Sang Pencipta.

Berikutnya kata Hyang Manon, yang digunakan dalam kalimat Saking kudrating Hyang Manon/mapan kinarya lantaran "dari kodratnya, Hyang Manon merupakan tempat yang dijadikan perantara (P.II.b11.3-4)”. Kata Manon berasal dari bahasa Jawa Kuno ton yang berkembang menjadi Manon, ton berarti "lihat, melihat, tahu'. Hyang Manon berarti Tuhan (Mardiwarsito, 1990: 340 \& 608), Yang Maha Mengetahui. Hyang Monon digunakan untuk menyebut nama Tuhan dalam tradisi budaya Jawa Kuno yang bernafaskan Hindu, tetapi masih digunakan dalam tradisi Jawa Baru yang bernafaskan Islam. Oleh karena itu, kata Hyang Manon dapat dikategorikan sebagai kata yang mengalami proses interkulturalisasi dari Jawa Kuna dan Jawa Baru.

el Harakah Jurnal Budaya Islam Vol. 19 No.1 Tahun 2017 
Kata Hyang dalam teks SSG juga mengawali kata Wasesa. Sehingga membentuk frasa Hyang Wasesa. Dalam teks SSG, kata ini digunakan hanya satu kali sebagai berikut.

Artatine wong tan wruh ing gaib/sapa kangwruh tan lyan Hyang Wasesa (P.III.b1:1-2)

[Sesungguhnya orang tidak tahu mengenai hal gaib, yang tahu hanyalah Hyang Wasesa]

Kata wasesa berasal dari bahasa Jawa Kuno yang berarti memerintah, berperintah (Zoetmulder \& Robson, 1995: 1398). Hyang Wasesa berarti sebagai 'Tuhan Yang Maha Memberi Perintah'. Akan tetapi, dalam konteks ini Hyang Wasesa diartikan Tuhan Yang Maha Mengetahui. Perubahan pemaknaan ini didasari kesesuian dengan konteks kalimatnya yang menyatakan bahwa hanya Hyang Wasesa yang mengetahui hal-hal gaib. Kata gaib sendiri berasal dari bahasa Arab yang artinya 'tidak tampak' (Mutahar, 2005: 256). Penggunaan kata yang berasal dari bahasa Arab dengan kata yang berasal dari bahasa Jawa Kuno menunjukkan adanya proses interkulturalisasi dalam kalimat tersebut. Mekanisme akulturasi nampak dari proses penyesuaian arti kata Hyang Manon dengan kata ghaib dalam kalimat tersebut. Selanjutnya, kata Hyang digabungkan dengan kata Widdhi, Pratandhane wujuding Hyang Widdhi / tuduh kinen muji Kang Akarya "Pertanda wujud dari Hyang Widdhi adalah adanya petunjuk tentang perintah untuk memuji Sang Pencipta dan Kang Akarya Jagad (P.III.b5:1).

Kata Hyang berasal dari bahasa Jawa Kuno hyang yang berarti 'dewa, dewi, yang dipuja sebagai dewa, Tuhan, dewa yang khusus bertalian dengan tempat (kraton, kayu, dsb)'; 'yang berhubungan dengan dewa; hal-hal yang suci, orang yang berbakti kepada kesucian, yang taat kepada agama, pertapa, biarawati, biarawan'; kata hyang sering berada di depan kata benda (Zoetmulder \& Robson, 1995: 373). Kata Widdhi berasal dari bahasa Sansekerta, yang merupakan perubahan dari $\sqrt{ }$ dhâ yang berarti injuction, command, rules (Macdonell, 1954: 284). Secara berurutan dapat diartikan sebagai 'keputusan, perintah, aturan' (Echols \& Shadily, 1989). Hyang Widdhi berarti 'dewa yang termulia, Tuhan' (Prawiroatmodjo, 1980: 320). Berdasarkan kutipan dan keterangan tersebut, dapat diketahui bahwa kata Hyang berada diawal kata Widdhi. Hyang Widdhi dalam konteks ini diartikan sebagai Tuhan Yang Maha Memerintah'. Hal ini dibuktikan dari baris selanjutnya yang diterjemahkan 'adanya petunjuk tentang perintah untuk memuji Sang Pencipta'. Kata ini sampai sekarang masih digunakan penganut agama Hindu di Bali. Hal ini membuktikan bahwa kata Hyang Widdhi merupakan wujud adanya proses interkulturalisasi. Kata Hyang Widdhi berasal dari dua bahasa yakni bahasa Jawa Kuna dan bahasa Sansekerta. 
Bilingualisme ini membuktikan bahwa kata Hyang Widdhi merupakan hasil dari mekanisme akulturasi.

Penggunaan kata Hyang di dalam frasa maupun secara mandiri dapat dikategorikan sebagai borrowing, karena merupakan bahasa Jawa Kuna yang digunakan dalam wacana Jawa Baru. Ketika kata Hyang bertemu dengan kata dari berbagai bahasa lain dalam frasa yang menunjukkan nama Tuhan, maka terjadilah proses akulturasi budaya. Adanya frasa Hyang Manon, Hyang Widdhi, Hyang Suksma, dan Hyang Wasesa dalam teks SSG yang merupakan teks berbahasa Jawa Baru membuktikan bahwa produk budaya Jawa Baru dihasilkan dari kontak budaya.

Dalam teks SSG, kata Widdhi tidak hanya digunakan dalam frasa Hyang Widdhi. Akan tetapi beberapa kali digunakan pula sebagaikata mandiri. Penggunaan tersebut dapat dilihat dalam kutipan berikut. Pramila gendhing yen bubrah / gugur sembahe mring Widdhi / batal wisesaning salat "oleh karena itu, jika gendhing rusak maka batallah sembahnya kepada (Widdhi) Tuhan” (P.I.b11:1-3). Penggunaan kata Widdhi dalam kalimat tersebut diartikan sebagai Tuhan yang menciptakan berbagai aturan, di antaranya adalah aturan dalam gendhing. Dalam kalimat berikutnya, wenanging gesang / ngrejaseng nugreng Widdhi "kemampuan manusia dalam hidup berawal dari anugerah", kata Widdhi disebut sebagai pemberi anugerah untuk manusia dalam memulai hidup. Kata widdhi, dalam kalimat Widdhi Widdhi wadi wada kamulyaning deya "kemuliaan Widdhi adalah perkataan yang rahasia" (P.V.b5.:1). Artinya, kata Widdhi mengalami proses akulturasi karena berasal dari bahasa Sansekerta dan digunakan dalam konteks kalimat berbahasa Jawa Baru. Bilingualisme dalam kalimat tersebut menunjukkan mekanisme interkulturalisasi dalam teks SSG. Dalam SSG, kata Sang Hyang Wasesa Jati hanya digunakan satu kali. Kata tersebut terdapat pada kutipan berikut.

Tuhya ri Sang Padmanaba / kekasihe Sang Hyang Wasesa Jati (P.IV.b14:2)

[Sungguh karena Sang Padmanaba merupakan kekasihnya Sang Hyang Wasesa Jati]

Kata Sang Hyang Wasesa Jati terbentuk dari empat kata, yakni Sang, Hyang, Wasesa, dan Jati. Oleh karena itu, kata tersebut akan diuraikan secara etimologis guna mengetahui proses interkulturalisasinya. Sang berasal dari bahasa Jawa Kuno yang berarti pertikel yang dipakai di depan kata benda penunjuk orang dari derajat tertentu (Zoetmulder \& Robson, 1995: 1018). Wasesa berasal dari bahasa Jawa Kuno yang berarti memerintah, berperintah (Zoetmulder \& Robson, 1995: 1398). Jati berasal dari bahasa Sansekerta yang berarti ‘nyata, tulen' (Prawiroatmodjo, 1980: 179). Sang Hyang Wasesa

el Harakah Jurnal Budaya Islam Vol. 19 No.1 Tahun 2017 
Jati dalam konteks ini diartikan sebagai 'Sang Tuhan Yang Maha Pandai'. Kata tersebut menunjukkan proses interkulturalisasi dari budaya Hindu dan budaya asli Jawa. Budaya India diwakili oleh kata Hyang dan Jati, sedangkan budaya asli Jawa diwakili oleh kata Sang dan Wasesa. Artinya, kontak budaya India (Hindu) dan Jawa terjadi dalam karya sastra berbahasa Jawa Baru.

\section{Pangeran}

Tuhan disebut juga dengan kata Pangeran. Kata Pangeran hanya digunakan satu kali, dalam SSG. Kata pangeran berasal dari bahasa Jawa Kuno yang berarti 'raja' (Zoetmulder dan Robson, 1995: 897). Pangeran juga berari 'panggilan kepada Tuhan (pendeta, tuan)' (Prawiroatmodjo, 1980:56). Untuk lebih jelasnya, dapat dilihat pada kutipan berikut:

Dene hakekat asaling gendhing / wus kanyatan ngelmuning Pangeran (P.III.b6:2)

[Adapun hakikat asal gendhing sudah menajdi kenyataan merupakan ilmu dari Tuhan].

Berdasarkan kutipan tersebut, dapat diketahui bahwa kata Pangeran berasal dari bahasa Jawa Kuno 'raja' tetapi dalam konteks ini diartikan sebagai 'Tuhan'. Kata Pangeran mengalami perubahan makna dalam bahasa Jawa Baru. Proses perubahan makna ini membuktikan adanya proses akulturasi dalam kata Pangeran.

\section{Allah}

Selain bahasa Sansekerta dan Jawa Kuno, SSG juga menunjukkan kontak budaya Islam. Hal ini dibuktikan dengan adanya kosakata dari bahasa Arab yang digunakan untuk menyebut nama Tuhan, di antaranya adalah kata Allah. Penyebutan kata Allah hanya terjadi satu kali. Untuk lebih jelasnya dapat diperhatikan pada kutipan berikut.

Wa amaburhana / wujudihi Allah Kudusul 'almi / tuhya gumlar ing jagad (P.III. b4:7-9)

[Dan adapun argument tentang wujud Allah Yang Maha Suci dan Maha Mengetahui adalah dengan adanya alam dunia]

Kata Allah berasal dari bahasa Arab Illahun yang berkembang menjadi Allah. Illahun dan Allah berarti 'Tuhan Yang Maha Esa'. Kudusul berasal dari kata quddusun yang berarti 'suci (tempat ibadah)', sedangkan kata 'almi berasal dari kata 'alima yang berarti 'mengetahui' (Mutahar, 2005: 141,853,\&768). Allah Kudusul'almi berarti 'Allah Yang Maha Suci dan Maha Mengetahui'. Dalam konteks penelitian ini kata tersebut mengalami proses interkulturalisasi, karena kata yang berasal dari bahasa Arab digunakan dalam konteks kalimat berbahasa 
Jawa Baru. Oleh karena itu, muncullah bilingualisme yang merupakan salah satu contoh adanya akulturasi budaya Islam dan Jawa. Penggunaan kata tersebut dalam suluk cukup beralasan karena suluk berisi ajaran manunggaling kawula Gusti dan bernafaskan Islam. Penggunaan kata Allah untuk menunjukkan adanya kontak budaya Arab dengan Jawa.

\section{Dat}

Selain kata Allah, digunakan pula kata Dat. Dat disebut beberapa kali dalam SSG. Penggunaan kata diperjelas pada kutipan-kutipan berikut.

Tukireng swara linuhung / amuji asmaning Dat".

Dat mutlak dipunwastani (P.II.b8:1)

Dat mutlak disebut latakyun.

Sajating panembah / wisesaning Dat mrih ayu (P.II.b11:1)

"Hakikat penyembahan adalah Dat Yang Kuasa"

Dat lawan sipatira / sastra gendhingipun / kang rasa lawan pangrasa (P.III.b8:6)

Dat dengan sifatnya, sastra dengan gendhingnya dan rasa dengan pangrasa.

Kata Dat berasal dari bahasa Arab daatun, yang berarti 'inti, pokok' (Mutahar, 2005: 536). Dalam bahasa Indonesia Dat disebut Zat, yang berarti 'wujud, hakikat (Allah); sesuatu yang menyebabkan sesuatu menjadi ada; bahan yang merupakan pembentuk (bagian-bagian yang mendukung) suatu benda' (Tim Penyusun, 1986: 1017).

Dalam SSG, kata Dat tidak diartikan sebagai 'inti' melainkan diartikan sebagai 'Tuhan'. kata Dat yang berasal dari bahasa Arab mengalami proses akulturasi ke dalam bahasa Jawa Baru seiring dengan masuknya Islam ke Jawa. Penggunaan kata Dat dalam kutipan-kutipan tersebut menunjukkan adanya proses interkulturalisasi dalam SSG.

Berdasarkan hasil temuan di atas, terdapat berbagai variasi nama Tuhan dalam teks SSG. Penggunaan variasi nama Tuhan dalam teks SSG menunjukkan adanya kontak berbagai budaya dalam teks Jawa Baru. Teks SSG merupakan sastra suluk yang diciptaan dalam keragaman latarbelakang budaya. Inti ajaran sastra suluk, yakni perjalanan manusia mencapai kesempurnaan hidup dalam nafas Islam menjadikan teks SSG kaya akan berbagai konsep Islam. Meskipun demikian, teks SSG tidak meninggalkan akar budaya Jawa yang direfleksikan dalam peminjaman berbagai nama Tuhan dari Bahasa Jawa Kuna ke dalam Bahasa Jawa Baru. Selain itu, bahasa Sansekerta juga tidak dapat dilepaskan dari proses penciptaan teks SSG, sehingga ditemukan pula variasai nama Tuhan dalam bahasa Sansekerta. Bahasa Sansekerta digunakan untuk memperkaya dan mengembangkan bahasa Jawa. Hal ini terjadi pula dalam teks SSG. Variasi 
nama Tuhan yang digunakan dalam teks SSG menunjukkan bahwa pencipta teks SSG secara sosiokultural dipengaruhi oleh perkembangan berbagai budaya pada masa tersebut. Pemilihan bentuk sebagai teks suluk digunakan oleh penulis teks SSG untuk menunjukkan misi teologisnya, yakni Islam. Akan tetapi, tidak secara langsung meninggalkan unsur teologisnya yang lama yakni Hindu. Untuk itu variasi nama Tuhan yang ditemukan merefleksikan adanya kontak budaya.

Penulis teks SSG merupakan produk sosial dan budaya Jawa pada masa pemerintahan Sultan Agung. Oleh karena itu dapat diasumsikan bahwa penulis tersebut merupakan wakil dari masyarakat Jawa pada masa tersebut. Penggunaan berbagai variasi nama Tuhan dalam teks SSG menunjukkan bahwa masyarakat Jawa sebagai masyarakat yang terbuka dan cenderung permisif. Kecenderungan tersebut tidak hanya dalam kehidupan sosial bermasyarakat saja, bahkan sampai pada sikap teologisnya. Keterbukaan dan sikap permisif jelas terlihat dari penggunaan berbagai variasi nama Tuhan dalam satu wacana.

Penggunaan variasi nama Tuhan dalam teks SSG menunjukkan mekanisme akulturasi terjadi tidak hanya dalam kehidupan bermasyarakat tetapi juga dalam kehidupan religius yang bersifat pribadi. Akulturasi ini terjadi karena penulis sebagai anggota kelompok masyarakat Jawa dihadapkan pada unsurunsur budaya asing yang berbeda, yakni budaya Hindu dan Arab. Namun demikian, budaya asing tersebut dapat diterima dan diolah dalam budayanya sendiri tanpa menghilangkan budaya aslinya. Hal ini terrefleksi dalam frasa Gusti Allah, Hyang Wasesa, Hyang Wasesa Jati, dan Pangeran yang merupakan bentuk perpaduan budaya Jawa dengan berbagai budaya asing.

\section{Simpulan}

Berdasarkan uraian di atas, dapat diketahui bahwa dalam SSG terdapat proses interkulturalisasi berupa variasi nama Tuhan. Variasi nama Tuhan yang terdapat dalam SSG berjumlah sebelas varian. Dari kesebelas varian tersebut, dapat diketahui bahwa kontak budaya yang melatarbelakangi penulisan SSG ialah budaya Hindu, Jawa, dan Islam. Budaya Hindu ditunjukkan dengan penyebutan nama Tuhan yang berasal dari bahasa Sansekerta yang berasal dari India bagian Utara. Nama Tuhan dalam SSG yang berasal dari bahasa Sansekerta ialah Pangeran, dan Widdhi.

Budaya Jawa ditandai dengan banyaknya kosakata Jawa Kuna yang digunakan untuk menyebut nama Tuhan. Nama Tuhan yang berasal dari bahasa Jawa Kuna ialah Hyang, Hyang Manon, dan Hyang Wasesa. Budaya Islam, 
ditandai dengan penggunaan bahasa Arab dalam penyebutan nama Tuhan. nama Tuhan yang berasal dari bahasa Arab ialah Dat dan Allah Kudusul 'almi. Adapun nama Tuhan yang berasal dari gabungan bahasa Sansekerta dan Jawa ialah Hyang Widdhi, Hyang Suksma, Hyang Wasesa dan Sang Hyang Wasesa Jati.

Proses interkulturalisasi tersebut, terkait erat dengan mekanisme akulturasi. Hasil dari kontak budaya Hindu dan Islam yang terdapat dalam teks SSG tersebut menandai bahwa karya sastra Jawa merupakan salah satu hasil dari proses interkulturalisasi. Hal tersebut sejalan dengan pendapat dari Salam (2011: 41), yang menyatakan bahwa karya sastra merupakan hasil dari proses interkulturalisasi yang panjang dari berbagai budaya.

Penggunaan variasi nama Tuhan merupakan upaya masyarakat Jawa dalam memahami dan mengimplementasikan ajaran Agama melalui kacamata kebudayaan Jawa. Selain itu juga sebagai upaya memasukkan unsur Islam dalam masyarakat Jawa yang telah memiliki keragaman budaya. Penggunaan variasi nama Tuhan sebagai upaya mempercepat penyebaran agama Islam di tanah Jawa.

Banyaknya variasi penyebutan nama Tuhan harus dipandang hanya dalam pengertian manifestasiNya. Setiap nama Tuhan tidak akan membuat lemah sifat ketuhanannya, karena semua nama tersebut merujuk pada sifat ketuhanan. Hal ini sejalan dengan pendapat Amstrong (2009:21), yang menyatakan bahwa konsep tentang Tuhan didasari oleh aspek kesejarahannya. Manusia merupakan makhluk sejarah sehingga nama-nama Tuhan juga muncul dalam wacana sejarah dan keagamaan. Manusia hidup dalam pluralitas etnik dan budaya, maka terjadi pluralitas dalam pemahaman dan penghayatan tentang Tuhan.

Pluralitas dalam pemahaman dan penghayatan tentang Tuhan mengakibatkan terjadinya pluralitas penyebutan nama Tuhan. Pluralitas nama Tuhan hanya dalam pengertian nama, bukan berarti politeisme (Kuswanjono, 2006: 84). Penyebutan nama Tuhan yang beragam ini didasari dari aspek kesejarahan dan keberagaman budaya yang melingkupi manusia. Dalam konteks sejarah, pemahaman ketuhanan menunjukkan berbagai warna yang terlihat dari keberagaman nama dalam penyebutan Tuhan, termasuk dalam teks SSG.

el Harakah Jurnal Budaya Islam Vol. 19 No.1 Tahun 2017 


\section{Daftar Pustaka}

Armstrong, Karen. 2009. Sejarah Tuhan. Bandung: Mizan.

Echols, John M., dan Shadily, Hasan. 1989. Kamus Inggris-Indonesia. Jakarta : Gramedia.

Haviland, William A. 1993. Antropologi Edisi ke-4, Jilid 2. Terjemahan R.G Soekadijo. Jakarta : Erlangga.

Imam S, Suwarno. 2005. Konsep Tuhan, Manusia, Mistik dalam Berbagai Kebatinan Jawa. Jakarta : Raja Grafindo Persada.

Koentjaraningrat. 1994. Kebudayaan Jawa. Jakarta: Balai Pustaka.

Kuswanjono, Arqom. 2006. Ketuhanan dalam Telaah Filsafat Perenial. Yogyakarta: Badan Penerbit Filsafat.

Macdonell, Anthony. 1954. A Practical Sanskrit Dictionary. London: Oxford University Press.

Mardiwarsito. 1990. Kamus Jawa Kuna Indonesia. Flores: Nusa Indah.

Mutahar, Ali. 2005. Kamus Arab-Indonesia. Jakarta: Mizan.

Salam, Aprinus. 2011. "Beberapa Catatan tentang Sastra (Indonesia) dalam Perspektif Interkuluralisme" dlm Jejak Sastra dan Budaya. Editor: Aprinus Salam, Henry Chambert-loir, M. Haji Salleh. Yogyakarta: Elmatera.

Simuh. 1988. Mistik Islam Kejawen Raden Ngabehi Ranggawarsita (suatu Studi Terhadap Serat Wirid Hidayat Jati). Jakarta: Universitas Indonesia Press.

1995. Sufisme Jawa Transformasi Tasawuf Islam ke Mistik Jawa. Yogyakarta : Bentang Budaya.

Strauss, A. \& Corbin, J. 2009. Dasar-Dasar Penelitian Kualitatif. Yogyakarta: Pustaka Pelajar.

Suyono, Ariyono. 1985. Kamus Antropologi. Jakarta: Akademi Pressindo.

Prawiroatmodjo, 1980. Baoesastra Jawa-Indonesia. Jakarta: Balai Pustaka.

Tim Penyusun, 1986. Kamus Besar Bahasa Indonesia. Jakarta: Balai Pustaka. 
Werdiningsih, Yuli Kurniati. 2006. "Serat Sastra Gendhing, Suntingan Teks dan Terjemahan”. Skripsi. Sastra Nusantara. Fakultas Ilmu Budaya Universitas Gadjah Mada Yogyakarta.

Woordward, Mark R. 2004. Islam Jawa: Kesalehan Normatif Versus Kebatinan. Yogyakarta: LKis.

Zoetmulder. 1983. Kalangwan, Sastra Jawa Kuna Selayang Pandang. Jakarta: Jambatan.

Zoetmulder \& Robson. 1995. Kamus Jawa Kuna-Indonesia. Jakarta: Gramedia 
